\title{
The Theory of Finance: A novel finance model being formed on the Internet
}

\begin{abstract}
The present paper argues that the present Internet conditions favour an entirely new finance model. Understood to soon supplement the existing ones (classical finance, corporate finance, and Islamic finance), it is argued that the new model will be defined by the destructive effect it is to have on the contemporary financial infrastructure of most countries, and the advent of the 'future money value exceeds its present one' principle.
\end{abstract}

Keywords: theory, finance, model, new, development, future, Internet

JEL Classification: G1, G2, G3, F3, E4, E6

\section{Introduction}

The present paper aims to establish the most likely path to be taken by global finance exposed to the rapid expansion of the Internet as a new sector of public and economic life. The original hypothesis underpinning it claims that a novel finance model is being formed on the Internet, an Internet finance model.

The structure of finance is generally recognised to include three fundamentally different models along which finances are organised: classical finance, corporate finance, and Islamic finance (see Table 1). The latter, it should be noted, ought to have been given a different term, since, theoretically, there could be other models of religious finance (as a more fitting general term), i.e. Judaic and Christian (based on Torah and the Bible, respectively), besides the Islamic finance proper. Despite the fact that only the latter developed into a functioning model (giving its name to the general principle of finance conducted in accordance with religious prescriptions and prohibitions), potential new Judaic, Christian, and other types of finance, if they, too, come into practice, would call for the more general term to be adopted.

The differences between the three models boil down to the following fundamentals. The classical finance model, which came about when money first began to be issued, regards its value as unaltered by the passage of time - that is, the value of a hundred dollars today is equal to the value of a hundred dollars due to be collected in a year's time.

The corporate finance model, which came about with the financial markets boom, regards money as losing its value with the passage of time.

Finally, the Islamic finance model, which came about with the rapid rise of Islamic economies, prohibits interest credit as one of its core principles, setting it apart from the other two models.

And still, the three models are all united by their underlying assumption that there is to be a single issuing centre (a central bank) and a strict state control over finances, so that one can say the three constitute a more general centralised finance model. 
Table 1

\begin{tabular}{|c|c|c|c|c|c|}
\hline \multirow[t]{2}{*}{ №№ } & \multirow[t]{2}{*}{ Parameters } & \multicolumn{3}{|c|}{ Existing models } & \multirow{2}{*}{$\begin{array}{l}\text { New model of } \\
\text { finance: } \\
\text { Internet finance }\end{array}$} \\
\hline & & Classical finance & $\begin{array}{l}\text { Corporate } \\
\text { finance }\end{array}$ & Islamic finance & \\
\hline & Origin & $\begin{array}{l}\text { Money being } \\
\text { first issued }\end{array}$ & $\begin{array}{l}\text { Development of } \\
\text { financial } \\
\text { markets }\end{array}$ & $\begin{array}{l}\text { Rise of Islamic } \\
\text { economies }\end{array}$ & $\begin{array}{l}\text { 1. Independent } \\
\text { access to the } \\
\text { Internet } \\
\text { 2. Independent } \\
\text { issuing of } \\
\text { money }\end{array}$ \\
\hline & Single issuing centre & Yes & Yes & Yes & No \\
\hline & $\begin{array}{l}\text { State regulation of } \\
\text { finances }\end{array}$ & Yes & Yes & Yes & No \\
\hline & Interest credit & Yes & Yes & No & Both possible \\
\hline & Future value of money & Unchanged & Lower & Unchanged & Greater \\
\hline & Aim of running a business & $\begin{array}{l}\text { Maximising } \\
\text { profit }\end{array}$ & $\begin{array}{l}\text { Maximising } \\
\text { capital value }\end{array}$ & $\begin{array}{l}\text { Maximising the } \\
\text { capital of an } \\
\text { 'immortal soul'* }\end{array}$ & $\begin{array}{l}\text { Maximising } \\
\text { personal } \\
\text { freedom of } \\
\text { action } \\
\text { (supposedly) }\end{array}$ \\
\hline & $\begin{array}{l}\text { Criteria of good business } \\
\text { performance }\end{array}$ & $\begin{array}{l}\text { Income exceeds } \\
\text { expenses }\end{array}$ & $\begin{array}{c}\text { Income exceeds } \\
\text { capital } \\
\text { maintenance } \\
\text { costs }\end{array}$ & $\begin{array}{c}\text { Prosperity } \\
\text { increased within } \\
\text { limits defined by } \\
\text { religion }\end{array}$ & N/A \\
\hline
\end{tabular}

* The term (suggested by the present paper's author), though not strictly academic, refers to the aim of a Muslim businessman's activities, attempting to maximise family and public wealth while strictly observing the many religious prescriptions and prohibitions.

It should be noted that in each case a new model only comes about at the time of a sudden boom in one of the spheres of a society's economic or political life. The historic rapid growth of financial markets brought about such developments as investment alternatives, giving, as a result, new meaning to the purpose of businessmaking (maximising one's profit). The sudden rise of Islamic economies made Muslim governments and businessmen ponder the correct (in religious terms) ways of investing their saving.

It is, therefore, logical to wonder what novel financial developments might be brought about by the explosive growth of the Internet ${ }^{1}$ and its phenomena? The hypothesis that prompted the present study had been the natural result of trying to find an answer to that question.

\section{Prior studies}

The search for other papers on the subject, conducted at the Social Science Research Network website (ssrn.com) by using the keywords 'Internet finance', yielded a total of 6 articles, which, given that a search for 'finance' and 'Internet' presented 19261 and 10022 articles, respectively, is very little.

\footnotetext{
${ }^{1}$ In 2014 the Russian sector of the Internet grew by 30\%; http://www.interfax.ru/russia/416717
} 
The only article coming close enough to dealing with the present paper's subject matter (Ping, Chuanwei, 2013) argued that Internet technologies such as mobile transfers, social networking sites, Internet search engines, and cloud computing will bring about a paradigm shift in the financial sector, ushering in a new mode of financial activities which the paper called 'Internet finance'. The paper featured a model of how the resources might come to be distributed in these new circumstances. Unfortunately, while pursuing the right avenue of research, its choice of online financial instruments to be analysed was limited to mobile transfers only, just one of the many services found online.

The second article (Best, 2005), though tagged as exploring 'Internet finance', only dealt with causes of the dotcom bubble and the fallout its collapse in early 2000s. The remaining three articles (Hasen, 2012; Brusoe, 2010; Hasen, 2008) analysed the way in which the Internet influences US laws on campaign finances and the new way of financing political campaigns.

In addition to that, a search of the Russian-language eLIBRARY.RU Online academic library was conducted using the relevant Russian keywords for 'Internet' and 'finance', yielding 6 articles, which, as was the case with ssrn.com, is very little, given that the number of papers dealing with 'finance' and 'Internet' was 19261 and 28698 articles, respectively. For the record, attempts to refine the search by adding keywords like 'theory' or 'model' returned no articles at all.

Of the papers mentioned, only three were at least partially relevant to the present paper's subject matter. The first of these (Morozova, 2014) advocated increasing election turnout by allowing Russian expats to cast their votes online.

The second one (Valent, 2010) analysed the results of an online poll entitled Do you endorse voluntary certification (including that of online services)? The answer, apparently, was yes.

And the last one (Vyrkovskiy, Makeyenko, 2012) predicted that online newspaper editions would soon cease to generate enough revenue to run as a standalone business or to justify abandoning paper editions.

It should also be said that there are great many papers describing the goods and services to be brought about by new technologies ${ }^{2}$. However, while visualising future developments in quality of life, they offer us no help in understanding the possible change in the relationship between individuals and businesses.

Summing up their conclusions, one can say that, while not addressing the theoretical new model of finance developed with the help of the Internet, they, nevertheless, recognise the fact that it is already offering alternatives to traditional services, which would sooner or later bring about a qualitative shift.

\section{Methodology}

Whether the original hypothesis is, indeed, plausible would be established by analysing the current state of affairs, with the Internet already steadily replacing real-world financial services with online equivalents, and the practical impact of some of the ambitious Internet projects to be realised.

\section{Current state of affairs}

Already there is a whole set of financial services that had traditionally been the monopoly of banks and financial institutions to be found online. Here are five of the most substantial ones.

\footnotetext{
${ }^{2}$ The ultimate presentation of which could, arguably, be found at http://www.futuretimeline.net/
} 
Firstly, online an individual can obtain digital currency (virtual money like Bitcoin or Litecoin), being issued in a decentralised manner, its purchasing power determined solely by the balance of supply and demand - in essence, one of the most important functions of a central bank.

Secondly, digital payment systems allow individuals not only to transfer funds to third persons, but also to manage their accounts, make payments, and exchange currency - in effect, acting as non-banking financial companies.

Thirdly, online an individual can make use of P2P (peer-to-peer) microfinance platforms where credit users and creditors are able to meet and transact deals regardless of their place of residence and other conditions. A deal can involve sums of up to several thousand dollars, usually for a couple of months only - an alternative to microfinance organisations.

Fourthly, there is the phenomenon of crowd funding, a service helping individuals to raise funds with an unlimited number of people for solving a particular task or implementing an investment programme. The availability of such a service chips away from the client base of commercial banks and financial companies.

Fifthly, there are shared economy platforms offering shared use of individuals' property, resources, time, and skills, turning them into 'micro-entrepreneurs'. Some estimates claim shared economy projects are providing part-time employment for 10 million individuals worldwide ${ }^{3}$, that is, providing citizens with workplaces - in effect, replacing the state.

All of this paves the way for entirely virtual commercial banks to be established - the first of which was, indeed, established in China on January 5, $2015^{4}$. The bank conducts its business $100 \%$ online by making use of face recognition technologies.

Also noteworthy are other Internet projects such as online voting systems that in the distant future have the potential to directly compete with national parliaments. For example, a number of governments running participatory budgeting schemes determine spending priorities for parts of their budgets through online voting ${ }^{5}$.

In addition to that, there are no technical barriers for projects like, for example, a virtual interbank lending market that could bring together short-term liquidity of most international banks, or a virtual Forex exchange market that could incorporate all the Forex markets worldwide. Moreover, there are no technical barriers to creating virtual stock markets capable of issuing IPOs.

All of the above signals that there already is a substantial opportunity on the Internet for replacing services currently being provided by real-word financial institutions.

\section{Ambitious near-term Internet projects}

There are currently five known major projects that have the potential to transform user interaction, including financial interactions, on the Internet.

First is the project to provide every person with free Internet access anywhere in the world. Facebook and Google ${ }^{6}$ are known to be planning to use high-altitude balloons and unallocated parts of radio spectrum for

\footnotetext{
${ }^{3}$ http://ilenta.com/news/internet/news_5216.html

${ }^{4}$ http://www.vestifinance.ru/articles/51616

${ }^{5}$ http://www.participatorybudgeting.org/

${ }^{6}$ http://lenta.ru/news/2014/09/06/facebook/
} 
that purpose. Also, SpaceX is known to be planning to launch some 700 telecom satellites ${ }^{7}$ capable of providing free Wi-Fi access anywhere on the planet.

Second are projects to move Internet servers of some companies to planes and ships located in international waters ${ }^{8}$. This can potentially further develop into moving servers into the Earth's orbit.

Third are plans by Internet giants to issue digital currency.

Fourth are projects to construct storage superfacilities capable of storing data on every online activity forever.

Fifth is the push to create a quantum computer, a development that would make encryption obsolete (at least for those not armed with a quantum computer themselves).

Also noteworthy are projects to create automated voice recognition, replace mobile with IP telecom, and the wide availability of cheap quality online education opportunities.

Taken together, these existing and potentially soon to be realised projects ought to generate a seismic shift.

\section{Consequences of further Internet development}

6.1. The advent of free and open Internet access would mean that consumers, aiming to secure their finances, but also their anonymity and privacy, would choose free orbital Wi-Fi over paid domestic landlines. Aiming to secure their independence and freedom from state control, website owners would likewise opt to host their sites on Internet servers located outside all national jurisdictions. One can then expect that, in all probability, most landline (and, eventually wireless) Internet access providers and datacentre owners would then go out of business, and state authorities would lose their control over online communications and website content. In particular, law enforcement agencies would no longer be able to intercept communications and gather evidence, but also block websites hosting illegal materials. The official Russian Internet blacklist would become obsolete.

In a situation where a computer signal gets sent via Wi-Fi directly to a geostationary satellite above, and then, through other satellites, to a server barge drifting in the Pacific, most states would no longer have any instruments or means whatsoever to control their citizens' communications. Consequently, a wide range of activists, from volunteers and opposition politicians, through extremists and terrorists, to, lastly, drug dealers and paedophiles, would set out to undermine the state and the society with impunity.

6.2. Against the backdrop of a significant lapse in state control of the Internet, there would be additional incentive to use virtual currencies as a further step towards greater personal freedom on the Internet. Incidentally, this notion of the Internet as an ungoverned self-regulated space has a lot of traction with a certain portion of Internet users.

Virtual currency would become especially popular with small and medium business, as well as private individuals. If technology enables transactions to happen immediately (instead of over a period of 10 minutes, as is currently the case with Bitcoin), then, given the decreased state control, using currencies like Bitcoin would become a reliable and secure means of reducing one's tax base. This would cause the entire turnover, previously in national currencies, to be redirected online.

Increased virtual currency use would result in decreased national currencies velocity. This, perhaps, is best illustrated by a simple example. Imagine an economy where there are two manufacturers: a manufacturer $Z$

\footnotetext{
${ }^{7}$ http://top.rbc.ru/technology_and_media/08/11/2014/545e174bcbb20f49da3e7cbd\#xtor=AL-[internal_traffic]--[rbc.ru][main_body]-[item_8

${ }^{8}$ http://www.rg.ru/2012/03/20/torrent-anons.html
} 
making food products and a manufacturer $\mathrm{S}$ making clothing. Over a year $\mathrm{Z}$ purchases 100 roubles worth of clothing, while $S$ purchases the same 100 roubles worth of food. With a money supply of 50 roubles, the velocity of money would amount to $4.0((100+100) / 50)$. Once other means of paying for goods and services, i.e. Bitcoin, become available, the amount of purchases in terms of goods would remain the same, while the rouble turnover would drop to a level that ensures zero income: $Z$ and $S$ would purchase, say, US dollars, convert them into bitcoins, and use the latter to conduct their payments. And their counterparties, having had purchased the roubles, would eventually put them up for sale, further affecting the rouble's exchange rate. It is, in all probability, the central bank that would be forced to buy them back, irretrievably spending its gold and foreign exchange reserves. Let us suppose the resulting rouble turnover falls down to 100 roubles, with a velocity of 2.0. It would mean that all the unused rouble stock would end up on the central bank's balance sheets as a dead weight. Moreover, the shadow and the criminal sectors of the economy would also switch to online currencies, further decreasing the demand for roubles.

In such a situation the central bank would have two main options: either to write down part of the rouble stock or, which seem more probable, to offer credit at a high enough negative interest rate. Recall that in classical and Islamic finance models the value of money doesn't change with time, while corporate finance regards a 100 roubles today as worth more than the same 100 roubles due to be collected in a year's time. However, the situation described above, while, too, making the value of money variable, makes it the exact opposite to that of the corporate finance: a 100 roubles due to be collected in a year's time would worth more than the same 100 roubles invested (deposited) today.

Ultimately, the spread of online currencies means that some countries would find their national currencies facing rival currencies, something human history never witnessed before, and central banks would have to compete hard for individuals and businesses to use their particular currency, arguing its security and stability of exchange rate. It would require not business but policy changes aimed at increasing efficiency of governmental bodies, the legality of power transition and its continuity - the essential factors in boosting the confidence in a currency.

One can also surmise that smaller countries with relatively small money supply and gold and foreign exchange reserves would in effect lose their national currencies altogether, as it might happen that to satisfy domestic needs it suffices to conduct all the transactions in a virtual currency like bitcoins.

A substantial budget deficit, brought about by a fall in tax revenues, will become a reality. A fall in revenues would mean cuts in spending, the pain of which a society will feel all too well. Still, it is conceivable that Internet users would themselves start raising funds (in bitcoins, for example) necessary to fulfil certain statutory goals of publicly owned institutions (schools, hospitals, maternity centres, museums, etc.). All in all, one can expect a change in budget spending regarding both its targets and the amounts spent. For countries with a large welfare budget, this is bad news promising mounting social tension.

And should the central bank, instead of writing off excess stock of money or offering it as cheap credit, choose to lend to the state to cover the deficit left by falling revenues, this will result in rising prices, inflation, and a further drop in the national currency's exchange rate.

6.3. Business requires stability. If digital currencies manage to deliver it, there will be a new, very powerful impulse to globalisation. The fact that national segments of the Internet cannot technically isolate themselves from the rest of the network will only help that. Storage superfacilities capable of storing data on every online activity forever will enable detailed profiles of every Internet user regardless of their nationality that would be in demand among businesses wishing to develop marketing strategies and politicians looking for political strategies. Great precision in forecasting a client's reaction to this or that marketing move would help substantially improve sales performance and properly diversify sales across different regions. In addition to 
that, individual marketing strategies aimed at selling goods to a particular customer known to a retailer by their IP address becomes a real prospect.

However, stability can be compromised with the arrival of a quantum computer capable of paralysing any online currency platform, breaching security mechanisms of any bank, exchange, or tax haven, identifying personal data of any individual, and decrypting classified data of any nation state. There will obviously no longer be any bank secrets (from governments). An Internet user armed with a quantum computer will essentially make themselves a super-administrator over the whole Internet. That would require them to assume a number of obligations aimed at placating the rest of the users. A government possessing a quantum computer would obviously completely ensure its currency's future.

Despite the threat posed by supercomputers, the prospects for Internet development are huge indeed. With universal worldwide access, one can expect IP telecom to replace mobile phones and, consequently, mobile carriers to go bankrupt. Other developments might include mass access to cheap quality education marketed by top international universities, anonymous Internet browsing (not having to disclose one's personal data), and logging into websites via voice and face recognition. All of the above will result in an upsurge in Internet user base and the amount of time spent online.

\section{Conclusions}

Active development of the Internet would in the very near future result in:

1. A revision of the concept of 'national sovereignty': the state losing control over its citizens' activities on the Internet, the citizens abandoning national currencies, unfettered mass tax avoidance calling into question the very existence of many of the nation states. Expect national boundaries to get redrawn worldwide.

2. The formation of a new model of finance characterised by decentralised emission of money, the dying out of most national currencies, decreased budget spending partially replaced by private funding, and the new investment paradigm of 'money due to be collected in the future value more than those currently in possession of'.

3. New financial conundrums, including how to control the money stock and liquidity in the banking system in the new circumstances, how to collect taxes and set the budget, how to evaluate risk and profitability of investment.

Given the fact that national segments of the Internet cannot technically be isolated from the rest of the network, some states would try to effect countermeasures like forcing users to go online under real names (entering ID details), making it more difficult to make purchases online by limiting what shipments can cross their physical borders, setting up Wi-Fi jamming stations, criminalising online currency, and, as the last resort, sinking server-basing ships and shooting down satellites. Still, these measures might fall short of stamping out the Internet's potential for development which is driven by demand from billions of citizens of the world. Therefore, it seems more expedient to start preparing for the inevitable and learn to live in the new circumstances.

\section{References}

1. Xie Ping, Zou Chuanwei. The Theory of Internet Finance. March 8, 2013. Volume 8, Number 2, MarchApril 2013, China Economist. Electronic copy available at: http://ssrn.com/abstract=2235967 
2. Kirsty Best. Celebrity.com: Internet Finance and Frenzy at the Millennium. Consumption, Markets and Culture, Vol. 8, Issue 4, 2005. pp. 361-378, 2005. Electronic copy available at:

http://ssrn.com/abstract $=1286014$

3. Richard L. Hasen. Chill Out: A Qualified Defense of Campaign Finance Disclosure Laws in the Internet Age. Journal of Law and Politics, 2012, UC Irvine School of Law Research Paper No. 2011-46. Electronic copy available at: http://ssrn.com/abstract $=1948313$

4. Peter W. Brusoe. Campaign Finance and the Internet: Disclosure, Information, and Policy Possibilities. 2010. Electronic copy available at: http://ssrn.com/abstract $=1547256$

5. Richard L. Hasen. Political Equality, the Internet, and Campaign Finance Regulation. Forum, Vol. 61, Article 7, 2008, Loyola-LA Legal Studies Paper No. 2008-11. Electronic copy available at: http://ssrn.com/abstract=1116774

6. Морозова О.С. Участие граждан, находящихся за рубежом, в национальных выборах: зарубежный опыт и отечественная практика. Фундаментальные исследования, №5-4, 2014. С. 876880

7. Валент Е. Нужна ли добровольная сертификация? Век Качества, №1, 2010. С. 28-29

8. Вырковский А.В., Макеенко М.И. Конвергенция в российской ежедневной прессе: экономические особенности и перспективы. Вестник Московского университета. Серия 10: журналистика, №5, 2012. С. 36-49 